DOI: $10.1515 /$ pof-2015-0016

VOLUME 7, ISSUE 3, 2015

ISSN: 2036-5438

\title{
Free Movement of Persons and European Solidarity \\ Revisited
}

by

Stefano Giubboni*

Perspectives on Federalism, Vol. 7, issue 3, 2015 


\begin{abstract}
This paper analyses the case-law of the European Court of Justice on the scope and limits of cross-border access of economically inactive Union citizens to national systems of social assistance. The author de-constructs and challenges the weak rhetoric of transnational solidarity generously deployed by the Court of Justice at the beginning of the expansive cycle of its case-law on the transnational social protection rights of mobile EU citizens. The most recent case-law shows, in fact, a spectacular retreat from this rhetoric in tune with the neo-nationalistic and social-chauvinistic moods prevailing in Europe.
\end{abstract}

\title{
Key-words
}

European citizenship; free movement of persons; cross-border access to national welfare systems; transnational solidarity. 


\section{Prologue}

For almost fifteen years, the saga of the constitutionalization of European citizenship has been based on the famous promise of 'a certain degree of financial solidarity' ${ }^{\text {II }}$ between the nationals of different Member States. The idea that a Union citizen could have access to a new 'status of social integration' (Azoulai 2010: 1), directly defined at the supranational level, and derived from the fundamental freedom of movement, actually seemed to be able to open up a new constitutional dimension to European citizenship, finally destined to transcend the nation-States' particularistic allegiances in order to revive and expand the universal and 'omni-inclusive' (Margiotta 2010: 7) promise of a society of free and equal individuals built on the jus-naturalistic foundations of modern citizenship.

The process of constitutionalization of the weak provisions on citizenship introduced by the Maastricht Treaty ${ }^{\text {II }}$ has been carried out by the European Court of Justice along two convergent trajectories, beginning with the path breaking case of Martínez Sala. ${ }^{\text {III }}$

On the first trajectory, a new universal status for transnational access to social rights on an equal footing with the nationals of the host country was progressively attached to the freedom of the European citizen to move and establish residence in another Member State, irrespectively of their status of economic activity. As a result of this, the main feature of this first jurisprudential movement can be identified in the fact that the Court of Justice has progressively extended those same powerful mechanisms of de-nationalization (and partly of de-territorialization) of social citizenship rights to every citizen of the Union qua talis.

These mechanisms had originally been reserved by the Treaty of Rome for economically active persons, and to workers in particular, as a fundamental means for the functional integration of the common market (Giubboni 2014). The fragility of this first ideational-pillar, in such a sophisticated endeavour of making European citizenship the fundamental status of the individual in the European Union's constitutional order, is probably due to the intrinsic contradiction pervading the conceptual categories used by the Court for such an ambitious purpose. The attempt to overcome the functionalistic logic 
and the mercantile ratio, historically underpinning the guarantee of social security rights to migrant workers (Mancini 2000: 123), actually took place through a sort of radicalization and generalization of those same conceptual premises under the new universalistic and unifying rhetoric of European citizenship. However, for this very same reason the pseudouniversal allure of transnational social solidarity, expected to stem from European citizenship, could not (and cannot) sever the original connection with the market citizen construct, ${ }^{\mathrm{IV}}$ which has overbearingly reemerged (and re-surfaces) during the hard times of EU crisis. The 'resilience' of such a model (Nic Shuibhne 2010: 1605) - and the reappearance of its intrinsic limits - is therefore actually due to the contradictions underlying the attempt to promote the status of social integration of European (economically inactive) citizens over and above an individual freedom of movement built in the image and likeness of the transnational economic actor (Somek 2007, Somek 2012, Menéndez 2010).

The other trajectory for constitutionalization is even more ambitious as, in Zambrano, ${ }^{\mathrm{V}}$ it brought the Court's influence to bear in the overcoming of the transnational perspective, in a view of 'disconnecting citizenship from mobility' (Margiotta 2010: 150). The integration-loop potentially envisioned by such a move would have actually brought the constitutional trajectory of European citizenship to a sort of federal completion, in so far as the Union would no longer be seen simply as 'the sum of the physical territories of the Member States' but as 'a new common space, a space of distribution of rights and common values' (Azoulai 2011: 34).

But this second trajectory, based on even more fragile assumptions, was soon interrupted, even before the new territories of the common space of distribution of rights and political values could be explored by their unknowing and disoriented holders. The great crisis has, rather, precipitated in the Union a new terra incognita, which is exactly the opposite of the land promised by the Maastricht Treaty. Instead of welcoming the 'magnificent and progressive destinies' Europe, tightened by the political project of common citizenship and currency, the great crisis has created deep rifts of division and reciprocal distrust between the Member States, threatening the disintegration of the whole project, above all beginning with the recurring risk of the fracture of the Eurozone. 
This paper gives a critical overview of the rapid rise and equally sudden decline of the normative ideal of European citizenship as a status of transnational social integration. The tipping points can be quite easily identified with the great changes that have diverted the course of European integration since the mid-00s; the cumulative effect of the big-bang Eastern enlargement, and the great political-financial crisis of the Eurozone, have totally altered the political economy of European integration and irreversibly degraded the optimistic and neo-illuminist assumptions underpinning the normative ideal. The Court's case law - especially with the much discussed Brey ${ }^{\mathrm{VII}}$ and Dano ${ }^{\mathrm{VIII}}$ judgments - shows a clear retreat, or maybe a retrenchment, in the discourse on EU citizenship as a source for transnational social solidarity, with an indisputable step back to a strict functional interpretation of the Treaty provisions in their relationship with secondary law (Directive 2004/38/EC and Regulation No. 883/2004).

Nonetheless, it is always risky and probably premature at this stage to gamble with predictions on possible future directions (Nic Shuibhne 2015). In a hypothetical European reform agenda, alternative paths would still be available; moreover the effective meaning of Brey and Dano is sufficiently ambiguous to leave such alternative interpretative pathways open. However, optimism on the democratic and socially-inclusive future of European citizenship is hardly compatible with the political dynamics dominant within the Union nowadays. It is no coincidence that the proposals recently announced by the European Commission with the Labour Mobility Package seem broadly consistent with the overall regressive itinerary that the Union entered while undergoing a crisis, which calls into question, above all, its identity and finalité.

\section{Transnational solidarity in its ascending phase}

As already mentioned, 'during the golden era of the Welfare State a concrete freedom of movement was inconceivable without the guarantee of the right to social security' (Margiotta 2010: 55). This is the reason why free movement rights of workers and, even before, the social security coordination system, introduced in 1958, could be considered as an embryo of European citizenship. ${ }^{\text {IX }}$

The Court of Justice's case law played a decisive role during the founding phase of the constitutionalization of the Community legal order, especially in relation to the freedom of 
movement and social rights of migrant workers (Weiler 1991). During this heroic original phase of integration, when the constitutional bases of the common market were set, the freedom of movement of workers had been intended in a broader sense than suggested by the mere functional logic of market integration (Spaventa 2007: $2 \mathrm{ff}$.).

We should not forget that the Court has, on the one hand, accepted an extremely broad definition of worker, as far as it encompasses all the activities, having any effectiveness and a minimum of economic consistency, that are performed under the direction of a different person in return for remuneration. On the other hand, it allowed the holders of the fundamental freedom of movement, and their family members, to have access to the whole panoply of social rights guaranteed to the nationals of the host Member State under conditions of full equal treatment. As for the first aspect, the Court was able to extend the guarantee of equal treatment in the host Member State - according to the current Art. 45 of the TFEU -to workers holding employment contracts that differ from the standard model of the permanent full-time job, already undermined during the early Eighties by the gradual spread of atypical work-relations. As for the second, the Court assigned an important integrative function to the guarantee of equal treatment, generally extended to social advantages by Art. 7 of Regulation No. 1612/68 into the domain of social assistance and welfare rights, thus opening up the inner circles of national solidarity systems to migrant workers and their families (Ferrera 2005: 53 ff.).

In this case law, 'social integration into the host society is seen by the ECJ as an instrument for promoting participation within the EU internal market and within its economic objective of free movement of factors of production, even when their productivity may be rather low. The rationale behind this case law has more to do with the internal market than with combating of social exclusion, even if this actually contributes to the latter' (Verschueren 2012a: 217). The model of integration endorsed by the Court is certainly based on the idea that the migrant worker (and his/her family members) should be included, from the beginning and without exceptions, in the social protection system of the host Member State, in its entirety, as they contribute to the well-being of the society that is hosting them through their (albeit reduced) economic activity (Dougan and Spaventa 2005).

An outcome of social integration in the migrant's elected country of residenceextended to all persons whose contribution to the internal market is actually only potential 
or at the very best only indirect - had thus been already firmly secured by the Court's historical case law on the freedom of movement of workers and their families. If read in light of this acquis, it can be said that the judgments, through which the Court has extended the principle of equal treatment in the access to social and welfare rights acknowledged by the host country, also extended to economically inactive European citizens. These judgments, from the leading case Martinez Sala to Zambrano, have done nothing but generalize a status of social integration already widely acquired, although within a more limited perimeter.

This case law was supposed to have the merit of universalizing the logic of social integration originally anchored to the functioning of the internal market, as free movers not carrying out an activity of economic nature were included in the equal protection status based on European citizenship. The innovative feature of this case law was to be found in the universalistic projection of the model of transnational social solidarity, already preenvisaged by the Treaty of Rome in favor of economic migrants. Some have thus recognized a change in the very normative paradigm of European social solidarity; where access to the social protection systems of Member States was previously functional to the internal market's full effectiveness, according to such case law, it has now become an autonomous constitutive element of Union citizenship, widely codified by Directive $2004 / 38$, and is seen as a fundamental status of social integration totally unrelated to the mercantile ratio and the original idea of homo oeconomicus. In this view, a constitutional citizenship-status of transnational value was hence created (Azoulai 2010: 8), which overcoming the old category-based model of market-justice and occupational-solidarity underpins a general claim for social integration within the host Member State, which is not very different from the functioning of federal-type polities.

However, the fragility of this conceptual construction has been brutally exposed by the great EU crisis. Such an idea of compassionate transnational solidarity was built, in fact, on a huge misunderstanding (Barnard 2005), whose hypocrisy has been mercilessly revealed by the drama of the European crisis. The great crisis has quite inevitably dissolved any propensity of the northern-European core Member States to host EU foreigners in need in their (still relatively) generous welfare systems: as social chauvinism ineluctably resurfaced in face of the well-cultivated spectre of 'benefit tourism', the swift political reaction has been 
everywhere nothing but the closing of the porous borders of the so-called transnational solidarity.

Hypocrisy has indeed its shortcomings: in our case, such limits are all included in a post-modern model of abstract solidarity, which - in so far as it relies not on a common welfare and fiscal system but on the disposition of selected Member States towards the hosting migrants in social need - by definition cannot ensure for economically inactive European citizens either an unconditional freedom of residence, or equal access to the system of social protection of the host country, at least until the status of long-term resident has been acquired according to Art. 16 of Directive 2004/38/EC. In concrete terms, the right to take up residence in another Member State for a period exceeding three months remains conditional on the reverse-means test of having comprehensive health insurance coverage, as well as sufficient resources to prevent the economically inactive citizen from becoming a burden on that State's social assistance system (Art. 7 of Directive 2004/38/EC). And the unfortunate accident of becoming such an unreasonable burden on the host Welfare State system gives the national authorities the power of expelling the unwelcome parasitic EU citizen, although without making use of rude automatisms and in compliance with the principle of proportionality (Art. 14, par. 3). Moreover, transnational access to the social solidarity system of a Member State under conditions of equal treatment with its nationals is subject in any case to an incremental criterion, since the inactive Union citizen must show proof of a sufficient degree of integration into the society of the host country.

Such limitations to access have a specific ratio, which has reverted to showing all its selective duress and disciplining power following the great crisis. ${ }^{\mathrm{x}}$ The very roots, at least of the Eurozone crisis, lie indeed in the total lack of any real European solidarity, and it is not by accident that the most prominent structure of the new crisis-management-law of Europe is that authentic tribute to de-solidarization un-popularly known as Fiscal Compact (Supiot 2015: 8 ff.; Rodotà 2014: 126 ff.). As there is no form of Europeanization or sharing of national social protection systems, each Member State may legitimately require that access to its welfare system has to depend on a given substratum of social integration already legitimately acquired by the European citizen.

By necessity, the exclusively transnational dimension of social solidarity connected to European citizenship is confronted with this underlying tension (Giubboni 2007), which 
inevitably reemerges anytime a freedom of movement not functional to the needs of the market ends up impinging on the finances of the national Welfare State (De Witte 2012). And, if such a tension can easily be disguised behind a vaguely cosmopolitan and postmodern rhetoric of transnational solidarity in times of economic growth, more or less equally distributed among the Member States (Bellamy 2009), in times of crisis all of the illusory and dangerous fragility of the rhetoric is revealed. This is especially true when the new highly asymmetrical Eurozone economic-governance rules trace a non-negotiable line between the self-proclaimed financial virtues of the northern countries and the irresponsibility of the southern ones, dismantling any resemblance of isonomy within the Union. $^{\mathrm{XI}}$

In essence, this is the lesson learned from Brey and Dano.

\section{Brey and Dano}

It is worth remembering that thanks to one of the most acrobatic (and in fact most discussed) ${ }^{\mathrm{XII}}$ passages in the Martinez. Sala ruling, the Court of Justice had already come to infer that economically inactive European citizens might enter the scope of the ratione materiae of Art. 18 of the TFEU, derived from the simple exercise of the freedom of movement, even outside the conditions defined by Art. 7, par. 1, letter b) of Directive 2004/38/EC. That very fact could indeed be capable of attracting the mobile EU citizen within the perimeters of the principle of equal treatment, not least for the sake of having full access to the non-contributory social benefits in the host Member State. In Martinez. Sala, as well as in other later cases, the residence permit held by the economically inactive European citizen was actually granted not on the basis of EU law but according to national law (Verschueren 2012b: 47 ff., especially at 62). Nevertheless, the effective exercise of the freedom of movement and subsequent residency by Mrs. Martínez Sala was sufficient to include her situation in the scope of the principle of equal treatment irrespective of nationality (Van Der Mei 2005: 225-226).

However, whilst certainly daring, the passage appeared in line with the overall political meaning of the interpretative efforts conducted at the time by the Court of Justice, which openly acted - both with that groundbreaking judgment as well as with other paradigmatic rulings of the same period ${ }^{\mathrm{XIII}}$ - within a bold perspective of the constitutionalization of the 
freedom of movement attributed to the European citizen by the Maastricht Treaty (Lenaerts 2011). In such a perspective, the conditions or limits posed by secondary law to the freedom of movement of the EU (economically inactive) citizen must be - coherently - very restrictively considered, while the maximum effet utile must be accorded to the rules of the Treaty in guaranteeing equal treatment in all relevant situations in order to effectively exercise that right magis ut valeat (Giubboni 2012: 186 ff.).

Michael Dougan has observed that, at least since the Förster ${ }^{\mathrm{XIV}}$ judgment of 2008, the Court of Justice's constitutional narrative has gradually undergone some reshaping with an undeclared 'backtrack from the technique of indirect judicial review previously cultivated by its case law on Union citizenship' (Dougan 2013: 141). Nonetheless, in its essence such a constitutional path had not been systematically abandoned by the Court, at least until Brey. The Brey judgment marks in our opinion the first essential separation from the expansive logic of Union citizenship as a fundamental status of Member States nationals, since it marks a paradigmatic retreat to a sort of interpretative legalistic-minimalism, according to which secondary law rules - strictly - determine the applicative limits of the Treaty, and not conversely.

Whilst Brey has an irresistible ambiguity (Verschueren 2014), it seemingly does not as yet imply a significant retreat from the old judicial course in respect of the degree of social solidarity 'among strangers'. In the judgment, in fact, the Court confirms that EU law requiring a certain degree of transnational solidarity - precludes the consideration of the mere fact of the application for social assistance by an economically inactive citizen of a Member State as sufficient to prove that the s/he has become an unreasonable burden for the welfare system of the host country, therefore depriving her/him of the right to reside in that country. The Court also states that the competent national authorities are entrusted with the task, and the duty, to carry out a careful assessment of the specific characteristics of each individual situation according to the principle of proportionality, without there being any automatic consequence attributable to the request of enjoyment of welfare benefits by the citizen of another Member State.

However, at the same time the Brey judgment prepared the ground which was soon after explored by Dano for the return to a tight functional interpretation - and a true deconstitutionalization - of the freedom of movement and residence of the Union (economically inactive) citizen, in two important aspects. 
Firstly, because the judgment anticipates the focus-point of the argumentative line carried out in Dano as being the relationship between Directive 2004/38/EC and Regulation No. 883/2004, it essentially attributes an improper hierarchical prevalence of the former over the latter. As stated in Brey, and then repeated in Dano, the main issue is whether the recourse to social assistance, and the request of a special non-contributory benefit according to Regulation No. $883 / 2004$ by the economically inactive citizen who has exercised his/her freedom of movement, would imply that the same European citizen risked losing the right to reside in the host country, as provided for by Directive 2004/38/EC under the conditions defined by Art. 7. And the Court's response was exactly that, for, even seen through the filter of the proportionality test, such a request for social assistance might actually endanger the status of legal residence under the Directive, due to the loss of the condition of economic self-sufficiency imposed by the latter in order to safeguard the financial stability of the welfare systems of the host Member States.

Secondly, because, among the possible configurations of the assessment of the alleged existence of an unreasonable burden on the public finances of a Member State, Brey accepts the most rigorous version, effectively defined by Daniel Thym as a 'systemic' evaluationtype as opposed to an 'individual' one (Thym 2015: 28-29). As elusive as it can be, the systemic-type of assessment in fact tends to privilege the importance of the overall implications that may impact on national public finances by the effective or potential increasing mobility of economically inactive Union citizens in need, therefore strengthening the protection of Member States' purses against - the real or imaginary - mal-practices of 'benefit tourism'.

Following the pathway opened by Brey, in Dano the Court of Justice took the decisive step to overturn the constitutional dynamic which, from Martinez. Sala onwards, has essentially promoted the access of economically inactive citizens to the welfare systems of the host countries based on conditions of equal treatment with their nationals.

For, firstly, only the fulfillment of the conditions of economic self-sufficiency (and of comprehensive health insurance coverage) imposed by Art. 7, par. 1, letter b) of Directive 2004/38/EC would grant the European economically inactive citizen the right to reside in the host Member State, and therefore to benefit from equal treatment in the access to social assistance benefits in the territory of the latter. And, secondly, only a prior condition of legal residence, under the requirements strictly set out by Art. 7 of the Directive, would 
allow the economically inactive citizen (who can prove also a sufficient degree of integration in the society of the host country) to access the welfare system of the latter, without putting in jeopardy the right of that citizen to reside in that State. Art. 24, par. 1, of Directive 2004/38, read in conjunction with Arts. 4 and 70 of Regulation No. 883/2004. This therefore does not prohibit Member States from excluding economically inactive European citizens from the enjoyment of a special non-contributory benefit which is acknowledged to their nationals, when those Union citizens do not enjoy the right to legally reside under Art. 7 of the Directive.

This is in fact a spectacular retreat from the 'magnificent and progressive destinies' of transnational solidarity towards the nationals of other Member States, that the Court has performed with sublime ease in name of a new European Realpolitik, which evidently urges for further reassurances to the hegemonic countries of the far North, both continental and insular. ${ }^{\mathrm{XV}}$ This new case law reintroduces a sharp line of demarcation in the European status civitatis, which goes back to obeying to a strict mercantile logic or, rather, to a new census model of citizenship.

Hence, 'Two citizenships' re-emerge (Belorgey 1998: 160 ff.), characterized by totally different protection statuses: first and second class (cf. Verschueren 2015a). First-class citizenship is reserved to persons that are active in the internal market (as workers or simply as providers or merely as individuals receiving services in return for remuneration) and to those who, while not being economically active, can nonetheless prove their economic self-sufficiency. Second-class citizenship, essentially devoid of any transnational protective status, is for the indigent. The latter, in fact, are trapped within a classic Catch-22 situation, ${ }^{\mathrm{XVI}}$ since in order to claim for social assistance in the host Member State this would almost automatically require, for them, giving evidence of not satisfying the requirements provided for by Directive 2004/38/EC in order to legally reside for a period exceeding three months.

From a technical point of view, the keystone of what, in hindsight, appears as the restoration of the system prior to the Maastricht Treaty, needs to be identified once again in the re-construction of the relationship between Directive 2004/38/EC and Regulation No. $883 / 2004$. And in relation to this, Dano falls firmly in the conceptual wake traced by Brey. 
As Rob Cornelissen and Herwig Vershueren have shown (Cornelissen 2013; Verschueren 2015b), the interpretation adopted by the Court in Dano in fact overturns the terms of the political compromise behind the contextual adoption of the Regulation and the Directive in 2004. This compromise reaffirmed the political balance already achieved in 1992 , ${ }^{\text {XII }}$ with the introduction of a special system of coordination for non-contributory cash benefits, characterized by the express and exceptional provision of a derogation to the general principle of exportability, albeit offset by the attribution of the responsibility of the payment of such benefits to the Member State of actual residence of the beneficiary according to the lex loci domicilii.

Yet, the notion of residence to this end, also used by Regulation No. 883/2004 for this very reason, is based on parameters that are inherently and essentially factual, as opposed to Directive 2004/38/EC, which gives a much stricter legal-definition instead, anchored as it is to requirements of legal-substantial nature. Therefore, the original idea was precisely that, as often as the merely factual situation of habitual residence in the host country recurred, ${ }^{\mathrm{XVIII}}$ the EU economically inactive citizens covered by the Regulations on social security would certainly be entitled to non-contributory benefits provided for by the legislation of the host Member State, in which that citizen placed his/her center of interests. Thus, at least within the semi-universal scope of application ratione personae of Regulation No. 883/2004, the right to have access to non-contributory benefits in the country of actual/factual habitual residence would certainly allow, or at least legitimately help, the European economically inactive citizen to meet the requirement of economic selfsufficiency set forth by Art. 7 of Directive 2004/38/EC.

Evidently, that compromise was overwhelmed by the interpretation of the relationship between the social security Regulation and the citizenship Directive endorsed by the Court in Brey and even more boldly in Dano. Only the status of legal residence - in full compliance with the Directive ${ }^{\mathrm{XIX}}$ - would allow access to special non-contributory/social assistance benefits under the specific conditions of equal treatment with the nationals of the host Member State. However, this means reintroducing a decisive cleavage within the status of Union citizenship, with a return to the previous deeply held normative ideal that, in the name of solidarity 'among strangers', was aimed at making EU citizenship the main constitutional vehicle for transnational social integration. 


\section{Epilogue}

Even after Dano, there are still many uncertain and controversial aspects that need to receive a conclusive answer from the Court. The jurisprudential framework is still developing and the darkest scenarios, although clearly visible on the horizon, hopefully do not necessarily need to take place, as Leopardi's insuperable pessimism on the unhappiness of human condition would predict.

Different interpretations of Dano, perhaps more in line with the socially inclusive idea of European citizenship endorsed in the ascending phase of the discourse on transnational solidarity, may still be possible, as Herwig Verschueren has tried to argue with his usual tireless and passionate argumentative accuracy (cf. Verschueren 2015b: 370 ff.). Indeed, Advocate General Whatelet, in his recent conclusions in Alimanovic, ${ }^{\mathrm{xx}}$ suggested that the Court follow a path firmly anchored to the context-sensitive and moderately sociallyembracing principle of proportionality.

However, our fear is that the most likely outcome, in line with the new neurotic and intolerant European Zeitgeist, is towards a creeping return to the grim logic of the Poor Laws, with a post-modern rediscovery of the classical remedy of the expulsion of the undeserving poor, by sending him back to the parish (or, in our case, to the country) of origin (Groenendijk 2013). It is no coincidence that, among the different hypotheses of reforms for providing a solution to the new transnational social question of mobile inactive union citizens, there are some that are impressively similar to the old 'non-resident relief', which under the Law of Settlement from the Elizabethan period exceptionally allowed for the prevention of the expulsion of the poor stranger if the parish of origin accepted to take on the burden of his assistance (Landau 1990; Hollen Lees 2007). The hypothesis according to which, at least partially or even temporarily, such a burden is to be transferred to the State of origin of the migrant European citizen, ${ }^{\text {xxI }}$ perhaps unwittingly (but no less clearly) echoes back to that historic tradition. And if this were to be actualized in the new context of the Union, the deep asymmetries already created by the great crisis between core and periphery countries would be exacerbated, again to the detriment of the Member States at the outer (Mediterranean or eastern) borders of the EU and to the benefit of the northern block under the German track (as well as the motherland of the Poor Laws, of course).

Moreover, pessimism is justified by the increasingly explicit and disturbing signs of an 
even more broad and general, not to say 'systemic', questioning of the postulates of the freedom of movement of persons, i.e. of workers, within the Union (cf. Editorial Comments 2014). One of these is now well-discernible within the case law of the Court of Justice, which more and more frequently - in a sort of reverse cross-fertilization demands that economic migrants, especially frontier workers, give proof of a certain degree of integration in the society of the host country in order to have access to social advantages and benefits on par with the nationals of that State. ${ }^{\text {XxI }}$ If this trend were to be consolidated, such an interpretative reorientation, or detour, would evidently undermine one of the pillars of the free movement within the internal market and of the model of social integration it embodied: that is to say, the unconditional right for migrant workers to have access to all the social benefits guaranteed by the host country (Art. 7 of Regulation n. 1612/68 and Regulation n. 492/2011). ${ }^{\text {XXIII }}$

And even the recent Labour Mobility Package, although not yet fully defined in its operational details, seems to be going in that same wrong direction, as I mentioned in the introduction to this melancholic eulogy on free movement of persons and European solidarity in the EU. The package would entail a substantial restriction of social protection rights of migrant workers, supinely endorsing once again the requests sent forth by the stronger northern European countries, and especially by Germany and the United Kingdom, which carry forward - in this regard - substantially convergent political positions.

If these scenarios of counter-reformation of EU law were to take place, we would be witnessing, as lost and disoriented as ever, not only the final and inglorious sinking of any misplaced hope of transnational social solidarity, but the deletion of an entire history of achievements of civilization in the long march towards the freedom of movement of workers in the European Union. Not only would it be a return to a de-socialized idea of market citizen, but a stronger premonition of the forthcoming disintegration of the whole European project.

\footnotetext{
* This article draws its inspiration from the author's participation in different conferences and seminars in 2015, all related to the crisis of European solidarity and respectively held in Antwerp on May 7 and 8 (Where do I belong? EU law and the adjudication on the link between individuals and Member States), Madrid on June 11 and 12 (Solidarity in hard times. Solidarity and the European social model in times of economic crisis), and York on September 4 and 5 (The impact of the financial-economic crisis on the guarantee of social welfare rights). An expanded and revised version of this article will be also published with Intersentia in an essay-collection edited by Herwig Verschueren. I take the opportunity to publicly express my gratitude to all participants in such events for
} 
their comments and suggestions; of course, the usual disclaimer applies.

I Case C-184/99, Grzelczyk, par. 44.

II 'Little more than a cynical exercise in public relations on the part of the High Contracting Parties', as was famously said by Weiler 1996: 1 .

III Case C-85/96.

IV Explurimis Everson 1995.

$v$ Case C-34/09.

VI To the benefit of the non-Italian reader, I would like to remind that this is the verse of one of Giacomo Leopardi's most famous poems, La ginestra, composed in 1836. The citation from John's Gospel, appearing in exergue, is also taken from Leopardi's poetry.

VII Case C-140/12.

vIII Case C-333/13.

IX Levi Sandri 1971: 941. See Giubboni 2008.

x Almost prophetic were the analysis dedicated to German Ordo-liberalism by Foucault 2005, especially at $113 \mathrm{ff}$.

XI On the importance of isonomy in the Aristotle's philosophy of justice classically see Perelman 1963: 9 ff., and Giuliani 1997: 3 ff.

XII See in particular the sharp criticism by Hailbronner 2005.

XIII See especially the judgment of 17 September 2002 in the case C-413799, Baumbast, in which, for the first time, the Court explicitly states the direct effect of the fundamental right to reside in the territory of another Member State granted to the European citizen by Art. 21 of the TFEU.

xIV Case C-158/07.

$\mathrm{XV}$ The influence of the bold political position expressed by the governments of Austria, Germany, The Netherlands and the United Kingdom in the conjunct letter addressed by the competent ministers of those countries to the presidency of the Union in April of 2013 is evidently perceivable. The main theme abruptly put on the political table was that limitations of the freedom of movement apply only to economically inactive citizens meeting the legal requirements set by Directive 2004/38/EC.

XVI Minderhoud 2015, at 15 of the mimeo. The reference is of course to the famous paradox/dilemma of Joseph Heller's 1961 novel Catch-22. Here, in order to avoid war service, a combatant can claim insanity, but such a claim, being the act of a rational person, would negate the effect of the claim and mean the combatant had to fight!

XVII Through Regulation No. 1247/92, that modified Regulation No. $1408 / 71$ by introducing the new subsystem for the coordination of special non-contributory cash benefits. Cf. Giubboni 1997.

XVIII See case C-20/96, Snares; case C-297/96, Partridge; case C-90/97, Swaddling.

XIX Further, see the judgment delivered by the Court in the joined cases C-424/10 and C-425/10, Ziolkowski and Sreja.

xx Case C-67/14, Jobcenter Berlin Neukölln vs. Nazifa Alimanovic and others.

XXI For a review of the various hypothesis of reform see Verschueren 2015a, especially at par. 4.

xxil Cf. case C-213/05, Geven; case C-379/11, Caves Krier, case C-20/12, Giersch.

XXIII Verschueren 2015c, at par. 5.

\section{References}

- Azoulai Loïc, 2010, 'La citoyenneté européenne, un statut d'intégration sociale', in Chemins d'Europe. Mélanges en l'honneur de Jean-Paul Jacqué, Dalloz, Paris, 1-28.

- Azoulai Loïc, 2011, 'Euro-Bonds. The Ruiz Zambrano Judgment or the Real Invention of Union Citizenship', Perspectives on Federalism, III(2): 31-39.

- Barnard Catherine, 2005, 'EU Citizenship and the Principle of Solidarity', in Dougan Michael and Spaventa Eleanor (eds), Social Welfare and EU Law, Hart Publishin, Oxford and Portland, Oregon, 157-180.

- Bellamy Richard, 2009, The Liberty of Post-Moderns? Market and civic Freedom within the EU, London School of Economics and Political Science, LEQS Paper No. 01/2009.

- Belorgey Jean-Michel, 1998, 'La protection sociale dans une union de citoyens', Droit social, no. 2/1998: 159-163. 
- $\quad$ Cornelissen Rob, 2013, 'EU Regulations on the Coordination of Social Security Systems and Special Non-Contributory Benefits: A Source of Never-Ending Controversy', in Guild Elspeth, Carrera Sergio and Eisele Katharina (eds), Social Benefits and Migration. A Contested Relationship and Policy Challenge in the EU, Centre for European Policy Studies - CEPS, Brussels, 82-110

- De Witte Floris, 2012, 'Transnational Solidarity in the Mediation of Conflicts of Justice in Europe', European Law Journal, XVIII(5): 694-710.

- Dougan Michael, 2013, 'The Bubble that Bursts: Exploring the Legitimacy of the Case Law on the Free Movement of Union Citizens', in Adams Maurice, de Waele Henri, Meeusen Johan and Straetmans Gert (eds), Judging Europe's Judges. The Legitimacy of the Case Law of the European Court of Justice, Hart Publishing, Oxford and Portland, Oregon, 127-154.

- Dougan Michael and Spaventa Eleanor, 2005, 'Wish You Weren't Here ... New Models of Social Solidarity in the European Union', in Dougan and Spaventa (eds), Social Welfare and EU Law; Hart Publishing, Oxford and Portland, Oregon, 181-218.

- Editorial Comments, 2014, 'The Free Movement of Persons in the European Union: Salvaging the Dream while Explaining the Nightmare', Common Market Law Review, LI(3): 729-739.

- $\quad$ Everson Michelle, 1995, 'The Legacy of the Market Citizen', in Shaw Jo and More Gillian (eds), New Legal Dynamics of European Union, Clarendon Press, Oxford, 73-89.

- $\quad$ Ferrera Maurizio, 2005, The Boundaries of Welfare. European Integration and the New Spatial Politics of Social Protection, Oxford University Press, Oxford.

- $\quad$ Foucault Michel, 2005, Nascita della biopolitica. Corso al Collège de France (1978-1979), Italian edition under the supervision of F. Ewald, Feltrinelli, Milano.

- Giubboni Stefano, 1997, 'Cittadinanza comunitaria e sicurezza sociale: un profilo critico', Argomenti di diritto del lavoro, III(6): 67-126.

- Giubboni Stefano, 2007, 'Free movement of Persons and European Solidarity', European Law Journal, XIII(3): 360-379.

- Giubboni Stefano, 2008, 'L'azione comunitaria in materia di sicurezza sociale in prospettiva storica. Omaggio a Lionello Levi Sandri', in Varsori Antonio and Mechi Lorenzo (eds), Lionello Levi Sandri e la politica sociale europea, Franco Angeli, Milano, 175-192.

- Giubboni Stefano, 2012, Diritti e solidarietà in Europa, il Mulino, Bologna.

- Giubboni Stefano, 2014, 'European Citizenship and Social Rights in Times of Crisis', German Law Journal, XV(1): 935-964 (Special Issue - EU Citizenship: Twenty Years On).

- Giuliani Alessandro, 1997, Giustizia ed ordine economico, Giuffrè, Milano.

- Groenendijk Kees, 2013, 'Access for Migrants to Social Assistance: Closing the Frontiers or Reducing Citizenship?', in Guild Elspeth, Carrera Sergio and Eisele Katharina (eds), Social Benefits and Migration. A Contested Relationship and Policy Challenge in the EU, Centre for European Policy Studies - CEPS, Brussels, 1-21.

- Hailbronner Kai, 2005, 'Union Citizenship and Access to Social Benefits', Common Market Law Review, XLII(5): 1245-1267.

- Hollen Lees Lynn, 2007, The Solidarities of Strangers. The English Poor Laws and the People (1700-1948), Cambridge University Press, Cambridge.

- Landau Norma, 1990, 'The Regulation of Migration, Economic Structures and Definitions of the Poor in Eighteenth-Century England', Historical Journal, XXXIII(3): 541-571.

- Leanerts Koen, 2011, 'European Union Citizenship, National Welfare Systems and Social Solidarity', Jurisprudencija/Jurisprudence, XVIII(2): 397-422.

- Levi Sandri Lionello, 1971, 'La sicurezza sociale dei lavoratori migranti nell'ambito della Comunità economica europea', in Riva Sanseverino Luisa and Mazzoni Giuliano (eds), Nuovo trattato di diritto del lavoro, III, Cedam, Padova, 941-972.

- Mancini Giuseppe F., 'The Free Movement of Workers in the Case Law of the European Court of Justice', in Mancini, Democracy and Constitutionalism in the European Union, Hart Publishing, Oxford and Portland, Oregon, 123-136.

- Margiotta Costanza, 2010, Cittadinanza europea. Istruzioni per l'uso, Laterza, Roma-Bari.

- Menéndez Agustín José, 2010, 'European Citizenship after Martínez Sala and Baumbast: Has European Law Become More Human but Less Social?', in Poiares Maduro Miguel and Azoulai Loïc (eds), 
The Past and Future of EU Law. The Classics of EU Law Revisited on the $50^{\text {th }}$ Anniversary of the Rome Treaty, Hart Publishing, Oxford and Portland Oregon, 363-393.

- $\quad$ Minderhoud Paul, 2015, Sufficient Resources and Residence Rights under Directive 2004/38, a paper presented at the workshop Where do I belong? EU law and the adjudication on the link between individuals and Member States, Antwerp, 7-8 May 2015.

- Nic Shuibhne Niamh, 2010, 'The Resilience of EU Market Citizenship', Common Market Law Review, XLVII(6): 1597-1628.

- $\quad$ Nic Shuibhne Niamh, 2015, 'Limits Rising, Duties Ascending: The Changing Legal Shape of Union Citizenship', Common Market Law Review, LII(4): 889-938.

- Perelman Chaïm, 1963, Justice et Raison, Presses Universitaires de Bruxelles, Bruxelles.

- Rodotà Stefano, 2014, Solidarietà. Un'utopia necessaria, Laterza, Roma - Bari.

- $\quad$ Somek Alexander, 2007, 'Solidarity Decomposed: Being and Time in European Citizenship', European Law Review, XXXII(6): 787-818.

- Somek Alexander, 2012, 'From Workers to Migrants, from Distributive Justice to Inclusion: Exploring the Changing Social Democratic Imagination', European Law Journal, XVIII(5): 711-726.

- Spaventa Eleanor, 2007, Free Movement of Persons in the European Union. Barriers to Movement in their Constitutional Context, Kluwer Law International, Alphen aan den Rijn.

- Supiot Alain, 2015, 'Introduction', in Supiot (ed), La Solidarité. Enquête sur un principe juridique, Odile Jacob, Paris, 7 ff.

- Thym Daniel 2015, 'The Elusive Limits of Solidarity: Residence Rights of and Social Benefits for Economically Inactive Union Citizens', Common Market Law Review, LII(1): 17-50.

- Van Der Mei Anne Pieter, 2005, 'EU Law and Education: Promotion of Student Mobility versus Protection of Education Systems', in Dougan Michael and Spaventa Eleanor (eds), Social Welfare and EU Law, Hart Publishing, Oxford and Portland, Oregon, 219-240.

- Verschueren Herwig, 2012a, 'Union Law and the Fight against Poverty: Which Legal Instruments?', in Cantillon Bea, Verschueren Herwig and Ploscar Paula (eds), Social Inclusion and Social Protection in the EU: Interaction between Law and Policy, Intersentia, Cambridge - Antwerp - Portland, 205-231.

- $\quad$ Verschueren Herwig, 2012 b, 'EU Free Movement and Member States' Solidarity Systems: Searching for a Balance', in Guild Elspeth and Minderhoud Paul (eds), The First Decade of EU Migration and Asylum Law, Martinus Nijhoff Publishers, Leiden - Boston, 47-74.

- Verschueren Herwig, 2014, 'Free Movement and Benefit Tourism: The Unreasonable Burden of Brey', European Journal of Migration and Law, XVI(2): 147-179.

- Verschueren Herwig, 2015a, 'Free Movement of EU Citizens: Including the Poor?', Maastricht Journal of European and Comparative Law, I(1): 10-34.

- Verschueren Herwig, 2015b, 'Preventing Benefit Tourism in the EU: A Narrow or a Broad Interpretation of the Possibilities Offered by the ECJ in Dano?', Common Market Law Review, LII(2): 363-390.

- Verschueren Herwig, 2015c, Being Economically Active: How it still Matters, a paper presented at the workshop Where do I belong? EU law and the adjudication on the link between individuals and Member States, Antwerp, 7-8 May 2015.

- $\quad$ Weiler J.H.H., 1991, 'The Transformation of Europe’, Yale Law Journal, C(8): 2403-2483.

- Weiler J.H.H., 1996, The Selling of Europe: The Discourse of European Citizenship in the IGC 1996, Harvard Law School, Jean Monnet Working Paper Series, 1996, No. 3. 